\title{
Evaluation by means of a survey about genetic knowledge in the clinical practice of ophthalmologists
}

\section{Evaluación mediante una encuesta del grado de conocimiento genético en la práctica clínica de oftalmólogos}

\author{
Bethania López-Star ${ }^{1 *}$, José F. Pérez-Pérez ${ }^{2}$, Priscila Sánchez-Moreno ${ }^{3}$, and Luis A. Ochoa-Ramírez ${ }^{3}$ \\ ${ }^{1}$ Area of Teleophthalmology and Epidemiology; ${ }^{2}$ Pediatric Ophthalmology and Strabismus; ${ }^{3}$ Telemedicine Unit. Instituto Mexicano de Oftalmología, \\ Queretaro, Queretaro, Mexico
}

\begin{abstract}
Purpose: To describe the results obtained by the application of a survey to a group of ophthalmologists who are members of the Asociación Mexicana de Oftalmología Pediátrica (AMOP), Sociedad Latinoamericana de Oftalmología Pediátrica (SOPLA) and Sociedad Panamericana de Retinopatía del Prematuro (SPROP), about practice patterns, diagnostic techniques, current knowledge, and future educational interests about ophthalmic genetic disorders. Methods: Cross-sectional, descriptive study. An online survey of 24 questions was shared through electronic invitations. Statistical analysis used descriptive statistics for the main variables, obtaining prevalences and expressing the results as percentages. Results: From the 100 physicians interviewed, $73 \%$ reported not carrying out genetic tests on patients with probable genetic eye disorders. Conditions as nystagmus, juvenile/congenital cataract and congenital glaucoma, were associated in $77 \%, 95 \%$ and $94 \%$, respectively, to have a genetic component in their etiologies. Fifty-five percent of physicians reported not being familiar with genetic diagnostic techniques. The interest of physicians to learn about applied genetics in their clinical practice is high (64\%), showing special interest in whole-exome sequencing. Conclusions: In the clinical practice of physicians, there is a deficien$c y$ in the recognition of diseases with a genetic origin, as well as in their diagnostic approach.
\end{abstract}

Key words: Knowledge. Genetic testing. Survey. Pediatric ophthalmology. Eye disorders. Genetic techniques.

\section{Resumen}

Objetivo: Describir los resultados de una encuesta realizada a oftalmólogos pertenecientes a la Asociación Mexicana de Oftalmología Pediátrica (AMOP), a la Sociedad Latinoamericana de Oftalmología Pediátrica (SOPLA) y a la Sociedad Panamericana de Retinopatía del Prematuro (SPROP), sobre el abordaje de patologías de probable origen genético, así como sobre el uso de pruebas diagnósticas, el conocimiento actual y el futuro interés de aprendizaje. Método: Estudio observacional y descriptivo. Se aplicó un cuestionario mediante una plataforma electrónica, el cual consta de 24 preguntas, que fue compartido por medio de invitaciones electrónicas. Se realizó un análisis estadístico descriptivo de las variables de interés y para cada una se obtuvieron las prevalencias para la muestra total; los resultados se expresaron como porcentajes. Resultados: De los 100 médicos entrevistados, el 73\% reportaron no realizar un abordaje diagnóstico con enfoque genético. Patologías como el nistagmo, la catarata juvenil/congénita y el glaucoma congénito se asociaron en un $77 \%$, un $95 \%$ y

Correspondence:

*Bethania López-Star

Avda. Estadio, s/n

Colinas de Cimatario, Centro Sur Date of reception: 05-08-2020

C.P. 76090, Santiago de Queretaro, Queretaro, Mexico

E-mail: bethania.lopez@imoiap.edu.mx

2604-1731/@ 2020 Sociedad Mexicana de Oftalmología. Published by Permanyer. This is an open access article under the CC BY-NC-ND license (http://creativecommons.org/licenses/by-nc-nd/4.0/).
Date of acceptance: 16-12-2020

DOI: 10.24875/RMOE.M21000163
Available online: 21-05-2021

Rev Mex Oftalmol (Eng). 2021;95(3):98-102

www.rmo.com.mx 
un $94 \%$, respectivamente, con un componente genético en su etiología. El $55 \%$ de los médicos reportaron no estar familiarizados con técnicas de diagnóstico genético. El interés de los médicos para aprender sobre genética aplicada en su práctica clinica es alto (64\%), mostrando un interés especial en la secuenciación completa del exoma. Conclusiones: En la práctica clínica de los médicos encuestados existe una deficiencia en el reconocimiento de patologías de origen genético, así como en su abordaje diagnóstico.

Palabras clave: Conocimiento. Diagnóstico genético. Encuesta. Oftalmología pediátrica. Patología oftálmica. Técnicas diagnósticas.

\section{Introduction}

Medicine is rapidly advancing within the realm of genomics, and the eye plays a major role in gene therapy. Currently, there are about 4000 genetic diseases or syndromes that affect man, of which a third have ocular involvement. In the area of ophthalmology, over the last three decades, the mapping of more than 300 genes and variants that cause inflammatory and hereditary eye diseases have been achieved ${ }^{1,2}$.

The most important causes of childhood blindness in high-income countries are brain visual deficit and optic nerve abnormalities, while retinopathy of prematurity and cataract are the most common preventable causes of blindness. A study carried out in the English population in 2006, documents a prevalence of congenital cataract of $1-3$ per 10,000 live births, of retinitis pigmentosa of 1 per 4000 live births, of retinoblastoma of 1 per 23,000 live births and of aniridia of 1.8 per 100,000 live births ${ }^{2}$. More than $60 \%$ of cases of blindness in childhood are caused by inherited diseases, such as congenital cataract, congenital glaucoma, retinal degenerations, optic nerve atrophy, etc. Likewise, $40 \%$ of patients with certain types of strabismus have a family history ${ }^{3}$.

On the other hand, low-income countries have seen the transition from disorders as to nutritional corneal opacities and congenital anomalies to disorders observed in high-income countries ${ }^{1}$.

The prevalence of diseases with genetic etiology reported in the Instituto Mexicano de Oftalmología in the period from January 1, 2018, to October 31,2019 , is of $1.09 \%$, similar to that reported in other studies. The most common conditions are retinitis pigmentosa, congenital glaucoma, cone dystrophy, corneal dystrophy, rod-cone dystrophy, cone-rod dystrophy, iris coloboma, and congenital cataract.

Genetic diagnosis based on DNA detection methods evaluates the predisposition of a patient for a certain disorder even decades before showing clinical manifestations, and also allows detecting the presence of multiple alterations simultaneously ${ }^{4}$, which has positive repercussions on the quality of life of the patient and the family, and helps to evaluate diseases that have an inheritable origin, such as retinal dystrophies, congenital glaucoma, congenital cataract, hereditary strabismus, color blindness, corneal dystrophies, atrophy and inherited optic neuropathies.

The development of molecular diagnostic techniques, such as next-generation sequencing, has allowed the identification of all the exome and specific sequences that cause inherited eye diseases, such as retinal degenerations, glaucoma and optic atrophy ${ }^{5}$. In a study published by Rim, et al. ${ }^{6}$, next-generation sequencing was used to study nystagmus at an early age, which led to the detection of other genetic alterations.

In 2016, The Genetic Eye Disease Task Force was created in response to a need of the American Association for Pediatric Ophthalmology and Strabismus (AAPOS). To begin with, they created a survey in order to evaluate the basic knowledge of the most common hereditary ocular diseases: the evaluation of patients, the understanding of genetic tests and the ability to identify patients with conditions of genetic origin that could be treated as part of systemic diseases. A total of 264 completed surveys were reported, and 11.7$34.1 \%$ of the participants reported having knowledge and using genetic diagnosis in their clinical practice?

In Mexico, few studies document the medical knowledge about molecular diagnostic techniques for the detection of inherited ophthalmological disorders. In a study carried out by the School of Medicine of the Universidad Panamericana, in 2015, a bioethical analysis was carried out on the knowledge and attitudes of ophthalmologists regarding genetic counseling for retinoblastoma. This analysis reported that $73.5 \%$ of them have found it necessary to provide advice to patients about the disease; however, only $26.5 \%$ demonstrated knowledge of the inheritance patterns of retinoblastoma ${ }^{8}$.

The objective of this study is to describe the results obtained by the application of a survey to a group of ophthalmologists who are members of the Asociación 
Mexicana de Oftalmología Pediátrica (AMOP), Sociedad Latinoamericana de Oftalmología Pediátrica (SOPLA) and Sociedad Panamericana de Retinopatía del Prematuro (SPROP), about practice patterns, diagnostic techniques, current knowledge, and future educational interests about ophthalmic genetic disorders.

\section{Methods}

This is an observational and descriptive study. The protocol was approved by the Research Committee of the Instituto Mexicano de Oftalmología.

A questionnaire was applied through an electronic platform (Google and "onlineencuesta.com") that consisted of 24 open-ended, closed-ended and multiple-choice questions, and was shared with ophthalmologists belonging to the AMOP, SOPLA and SPROP through electronic invitations, from November to December 2019. It was specified in the survey that the results would be anonymous and only used for academic purposes.

The questionnaire was obtained from a study conducted by Drack, et al. ${ }^{7}$, with prior authorization, and it was translated into Spanish, mentioning that the original questionnaire is not validated. A total of 100 responses were obtained. The selection criteria were to be an ophthalmologist and a member of the AMOP, SOPLA or SPROP societies.

The statistical analysis used descriptive statistics for the main variables, estimating prevalence and expressing the results as percentages.

\section{Results}

The electronic survey was answered by 100 ophthalmologists belonging to the aforementioned societies, of which $79 \%$ are dedicated within their clinical practice to teaching and $27 \%$ to research. Likewise, $56 \%$ practice private medicine, $21 \%$ in an ophthalmological hospital and $35 \%$ in public hospitals. Of the 100 participants, $73 \%$ work full-time and $27 \%$ part-time.

The interviewees reported that, on average per week, the majority $(70 \%)$ attend less than five patients with an ocular pathology of probable genetic origin, $15 \%$ from 5 to 10 patients, $4 \%$ more than 11 patients and the $11 \%$ reported not attending to this type of pathology. It was asked if they performed genetic studies on patients in whom they suspected a genetic origin of the disease, as documented in Figure 1.

We deliberately asked about the most relevant pediatric genetic pathologies in the consultation of an ophthalmologist, according to their prevalence, such as
Table 1. Main pathologies of probable genetic origin in the pediatric ophthalmology consultation

\begin{tabular}{|c|c|c|c|c|}
\hline & \multicolumn{2}{|c|}{$\begin{array}{l}\text { Is it a pathology } \\
\text { of potential } \\
\text { genetic origin? }\end{array}$} & \multicolumn{2}{|c|}{$\begin{array}{c}\text { Do you perform } \\
\text { genetic } \\
\text { diagnosis? }\end{array}$} \\
\hline & Yes & No & Yes & No \\
\hline Nystagmus & $77 \%$ & $23 \%$ & $21 \%$ & $79 \%$ \\
\hline $\begin{array}{l}\text { Juvenile/congenital } \\
\text { cataract }\end{array}$ & $95 \%$ & $5 \%$ & $67 \%$ & $33 \%$ \\
\hline Congenital glaucoma & $94 \%$ & $6 \%$ & $35 \%$ & $65 \%$ \\
\hline
\end{tabular}

nystagmus, juvenile cataract, congenital cataract and congenital glaucoma (Table 1), being congenital and juvenile cataracts mainly associated with a genetic pathogenesis (95\%).

Of all the physicians interviewed, regarding the tests used for genetic diagnosis, they reported a degree of knowledge that varies from $2 \%$ to $27 \%$. Fifty-five percent of physicians reported not being familiar with these techniques, $18 \%$ did not understand diagnostic tests in genetics, and only $1 \%$ fully understood them. On the other hand, the majority reported having an interest to learn and implement these diagnostic tests in their daily clinical practice, as shown in Figure 2.

\section{Discussion}

Based on the information obtained from the ophthalmologists surveyed, it stands out the deficiency to diagnose disorders of genetic origin, as well as a lack of knowledge of their diagnostic approach, since only $27 \%$ of doctors refer performing diagnostic tests, of which $78 \%$ end up referring the case to a geneticist.

According to the study carried out by Drack, et al. ${ }^{7}$, on which the present work was based, the highest percentage in baseline knowledge about diagnostic methods was $34 \%$, in the area of analysis of deletions and duplications, and the lowest was in diagnosis by Sanger sequencing, with $11.7 \%$; $48 \%$ responded that they were not familiar with these techniques. In contrast, in the present study, the highest level of knowledge reported (27\%) corresponded to the analysis of point mutations, and the lowest was reported for Sanger sequencing (2\%), while 55\% reported not being familiar with any diagnostic technique.

Regarding the association with genetic conditions, nystagmus was identified as of genetic etiology in $77 \%$, juvenile/congenital cataract in $95 \%$ and congenital glaucoma in $94 \%$, while in the study by Drack, et al. ${ }^{7}$ 


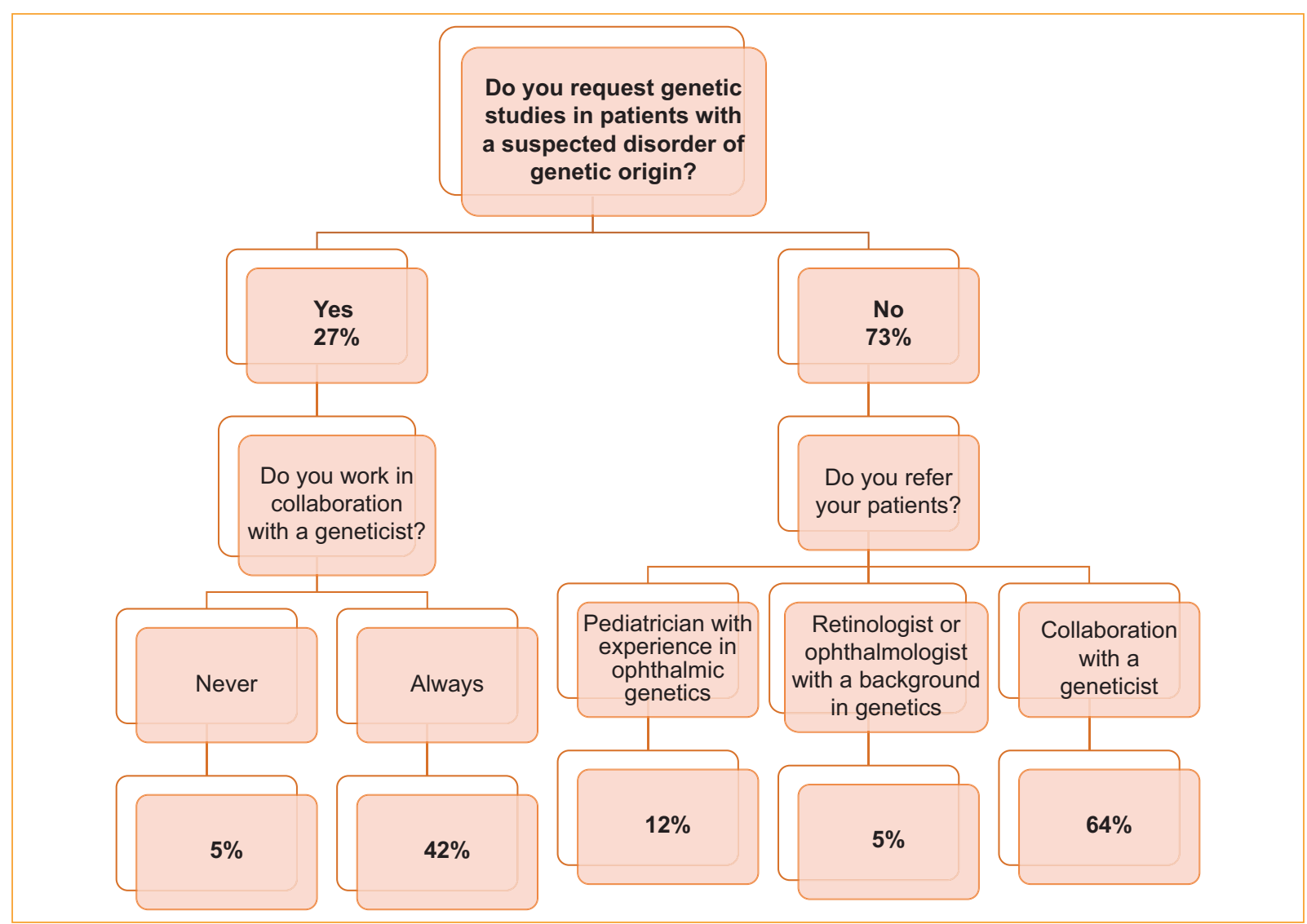

Figure 1. Flowchart of the diagnostic approach in patients with disorders of probable genetic origin in pediatric ophthalmology.



Figure 2. Current knowledge and future learning interest on genetic diagnostic techniques. 
physicians identified nystagmus in $75 \%$, cataract in $95 \%$ and glaucoma in $85 \%$.

Among the interviewees, according to the clinical practice, of those who work in an ophthalmological hospital, $61 \%$ responded that they felt capable of identifying clinical manifestations of genetic conditions and making timely referrals; from those, $74 \%$ work in a general hospital and $25 \%$ work in private practice.

The interest of physicians in learning about applied genetics in their clinical practice is high, with special interest in whole-exome sequencing (64\%) and the analysis of point mutations (61\%), while in Drack's study, et al. ${ }^{7}$ the greatest interest in learning was reported for analysis of point mutations $(73.5 \%)$ and next-generation sequencing (72.7\%).

The ophthalmologists surveyed suggested deepening genetic knowledge through the creation of online courses on applied genetics, congresses focused on genetics and collaboration with geneticists to prepare courses.

One of the limitations of the study is that the questionnaire is not validated; however, it reflects the importance of paying attention to the genetic approach of the ophthalmologic patient.

The measurement of medical knowledge about pathologies of genetic origin makes it possible to identify areas of opportunity within ophthalmology, as well as to promote learning about the genetics of ocular pathologies regarding diagnosis, treatment and prognosis, and to be able to provide advice as part of a multidisciplinary management.

The impact that genetic diagnosis has on the life of the patient may involve reincorporation into society and prevent complications by acting early. It seeks to prevent recurrence in the family, as well as to advise on molecular diagnostic tests for members who could be potentially affected. It also reflects the importance of using diagnostic algorithms applicable to the Mexican population, in order to provide specific and personalized treatment based on the most frequent genetic alterations.

\section{Conclusions}

In the clinical practice of pediatric ophthalmologists who answered the survey, there is a deficiency in the recognition of diseases with a genetic origin, as well as in their diagnostic approach. However, most ophthalmologists are keen to learn about applied genetics in their daily practice, especially about whole-exome sequencing, and analysis of point mutations.

\section{Conflicts of interest}

We declare that there is no conflict of interest of the authors or of the Instituto Mexicano de Oftalmología, so the results were not influenced in any way.

\section{Ethical disclosures}

Protection of human and animal subjects. The authors declare that no experiments were performed on humans or animals for this study.

Confidentiality of data. The authors declare that they have followed the protocols of their work center on the publication of patient data.

Right to privacy and informed consent. In the present work, no patient data were used, only an electronic survey that specified that the information shared would only be for research purposes. No personal data was included to maintain the anonymity of the participating physicians.

\section{References}

1. Solebo A, Teoh L, Rahi J. Epidemiology of blindness in children. Arch Dis Child. 2017;102:853-7.

2. Bunce $C$, Wormald R. Leading causes of certification for blindness and partial sight in England and Wales. BMC Public Health. 2006;6:58.

3. Cleveland Clinic. Inherited eye disease. (Consultado el 31 de diciembre de 2019.) Disponible en: https://my.clevelandclinic.org/health/diseases/17130-inherited-eye-disease.

4. Stone E, Aldave A, Drack AV, MacCumber M, Sheffield V, Traboulsi E, et al. Recommendations for genetic testing of inherited eye diseases. Ophthalmology. 2012;119:2408-10.

5. Consugar M, Navarro-Gómez D, Place E, Bujakowska K, Sousa M, Fonseca-Kelly $Z$. Panel-based genetic diagnostic testing for inherited eye diseases is highly accurate and reproducible and more sensitive for variant detection, than exome sequencing. Genet Med. 2014;17:253-5.

6. Rim JH, Lee ST, Gee HY, Lee BJ, Choi JR, Park HW, et al. Accuracy of next-generation sequencing for molecular diagnosis in patients with infantile nystagmus syndrome. JAMA Ophthalmol. 2017;135:1376-85.

7. Drack A, Miraldi V, Alcorn D. Survey of practice patterns for the management of ophthalmic genetic disorders among AAPOS members: report by the AAPOS Genetic Eye Disease Task Force. J AAPOS. 2019;23:223-6.

8. Morelos $\mathrm{P}$, Casas M, Juárez J, Villa A. Conocimiento y actitudes de oftalmólogos mexicanos acerca del consejo genético para retinoblastoma: análisis bioético. Rev Mex Oftalmol. 2016;90:276-83. 